José Ángel García Cuadrado, ed.

Los fundamentos antropológicos de la ley en Suárez. Colección de Pensamiento

Medieval y Renacentista (Pamplona: Eunsa, 2014). Pp. 256. 17 Euros.

This uneven volume brings together twelve papers presented in the "Symposium on Classic Spanish Thought," held at the University of Navarra in 2011, all preceded by a presentation by the editor, José Angel García Cuadrado. The official theme is the anthropological foundations of the Jesuit theologian Francisco Suárez's legal thought, although the contributors seem to have enjoyed considerable freedom.

The first chapter, by Constantino Esposito, is a long elaboration on the Heideggerian theme of Suárez as the initiator of modernity. The author draws parallels between Suárez's metaphysics and Suárez's legal thought. According to the argument, Suárezian metaphysics subsume God under the concept of being in such a way that the intelligibility of beings no longer requires acknowledgment of their origin in God. It is further suggested that a similar outlook informs Suárez's legal thought, apparently based on the thought that the human being is thinkable in a state of puris naturalibus, that is, in its pure nature, without connection to its supernatural end. This thesis has trouble in accommodating Suárez's fundamental view that law, natural and divine, is law insofar as it expresses the will of God. The style is cumbersome and mannerist, perhaps the result of a too literal translation into Spanish.

This stylistic problem is exacerbated in the second chapter in which JeanPaul Coujou provides an exposition of Suárez's theory of natural law and highlights its mutability and openness to human modification. Although the chapter is in Spanish, French syntax and punctuation have been left in place, resulting in a very difficult read. None of this happens in Lorenzo Velázquez's contribution which lucidly contrasts Suárez's conception of natural law with that of Rodrigo de Arriaga and Gabriel Vázquez, who, unlike (and against) Suárez, posit the existence of pre-positive moral prohibitions and injunctions. David González Ginocchio provides a detailed, original, well-written and thought-provoking analysis of the root of freedom in Suárez's analysis of the intellect, emphasizing Suárez's great debt to Scotus. This is one of the best chapters and one of the few that engages with the latest scholarship. It also includes as appendix a translation of Scotus's relevant texts.

Ángel Poncela González's chapter discusses state perfectionism in Aristotle, Aquinas, Soto, and Suárez, closing with some thoughts on the role of public morality in modern Spain. Manuel Lázaro Pulido traces back some of the traits of Suárez's analysis of law to Franciscan theologian Alfonso de Castro whose writings, in the author's opinion, reflect Scotus's relatively benign appraisal 
of human nature and free will (as compared to Bonaventure's grimmer Augustinianism). According to María Martín Gómez's contribution, it is the writings of Fray Luis de León which constitute the source (or a source) of Suárez's legal voluntarism. Her analysis, however, is too succinct to establish that conclusion. Idoya Zorroza's chapter provides a comprehensive, systematic, well written exposition of Suárez's theory of ownership/lordship (dominium) and its naturalness. In an original and interesting essay, Mauricio Lecón analyzes Suárez's arguments about the inapplicability of the law to non-human animals and brings these arguments in contact with modern philosophical discussions on the legal and moral status of those non-human animals that are closely related to us, such as some primates. Galina Vdolina's chapter studies the concept of esse morale in the later Scholastics (Suárez, but also Arriaga, Hurtado Mendoza, and others) from the perspective of semiotics. This learned, insightful, highly original and well-argued chapter uses Suárez's analysis of law to throw light on the Baroque conception of language as a social institution.

Two of the chapters fall outside the official theme of the book. One is Socorro Fernández's clear and concise exposition of Suárez's understanding of divine omnipotence. The second is Dimitry Shimonin's account of the history of professional philosophy in Russia and the late Scholastic - and quite marginal-influx in this process. It is difficult to see why this chapter was included in the collection.

Some of the stylistic defects of the book have been already pointed out. One should add that there is no bibliography, index or presentation of the authors. Typographical errors are not rare. In terms of substance the volume raises a different worry. It is customary to find in English-written studies on Suárez the apologetic remark that he has been unfairly neglected by the Anglo-Saxon scholarly community. This has been partly rectified in the last few years, which have seen a formidable explosion of English-written philosophical research on Suárez, as shown by collections of essays on Suárez published (or about to be published) in leading academic presses such as Brill, Cambridge, and Oxford. Little or nothing of these works has been taken notice of, let alone engaged, by the contributors to this volume even when they are directly relevant to their chosen topic. This sort of parochialism can do no good to Suarezian scholarship.

\section{Daniel Schwartz}

The Hebrew University of Jerusalem

daniel.schwartz3@mail.huji.ac.il

DOI 10.1163/22141332-00201005-17 